\title{
Organizational Performance: Are the Phases of the Talent Management Process Equally Important? ${ }^{1}$
}

\author{
Drahoslav LANČARIČ* - Radovan SAVOV** - Juraj CHEBEŇ***
}

\begin{abstract}
This study aims to assess whether the individual phases of the talent management process are equally important with respect to overall organizational performance. We analyse 381 business organizations in Slovakia. Authors use a linear regression model and ANOVA to evaluate the impact of the phases of the talent management process on the development of organizational performance of an organization and focus group approach to explain the differences in the individual phases of a talent management process. The results revealed that not all talent management phases equally influence the economic situation of the organization. The final two phases (development and retention) significantly influence the progress of the organizational performance while the initial phases (strategy, identification, and assessment) seem to have no impact on organizational performance. Financial efficiency should prioritize Retention, and only after focus on Development of talents. Remaining resources should be invested into Strategy, Assessment, and Identification of talented people.
\end{abstract}

Keywords: talent management process, individual phases importance, organizational performance, economic situation

JEL Classification: M12, M51, M53, O34

DOI: https://doi.org/10.31577/ekoncas.2021.10.03

\footnotetext{
* Drahoslav LANČARIČ, Slovak University of Agriculture in Nitra, Institute of Economic Policy and Finance, Tr. A. Hlinku 2, 94976 Nitra, Slovakia; e-mail: drahoslav.lancaric@uniag.sk

** Radovan SAVOV, Slovak University of Agriculture in Nitra, Institute of Economics and Management, Tr. A. Hlinku 2, 94976 Nitra, Slovakia; e-mail: radovan.savov@uniag.sk

*** Juraj CHEBEŇ, Comenius University, Department of management, Odbojárov 10, 82005 Bratislava 25, Slovakia; e-mail: j_cheben@yahoo.com

${ }^{1}$ This work was supported by the Scientific Grant Agency of the Ministry of Education of the Slovak Republic (ME SR) and the Slovak Academy of Sciences (SAS) under the contract No. VEGA-1/0525/21 and under the contract No. VEGA-1/0504/21.
} 


\section{Introduction}

Human resources form an important competitive advantage for the firm (Chakraborty et al., 2020, p. 69), have a big impact on the contribution to achieve business results (Trivedi et al., 2019, p. 99; Zirar et al., 2020, p. 28), and has fundamental influence on companies' sustainable business (Horváthová et al., 2020, p. 245). Many academics and practitioners (see Tansley, 2011, p. 270; GallardoGallardo et al., 2013, p. 294) focus on talent in business context, especially on skills and abilities of individuals required for today's and future organisational purposes (Ulrich et al., 2012, p. 57; Ozel et al., 2019, p. 291). Usually in business practice, the word talent means the high potential employees who are strategically important, these employees are in key positions, and represent $20 \%$ of the workforce. They also receive more valued resources and career challenges ( $\mathrm{N}^{\prime} \mathrm{Cho}$, 2017, p. 626). Talent has the potential to create value and rivals cannot easily copy it. Building and sustaining talents is a critical issue of the executives (Joyce et al., 2012, p. 186). Human resource management (HRM) focuses on attracting, hiring, training, and retaining of employees and the talent management works as a part of it. The focus of talent management is to attract talents in order to achieve more organizational goals and bring the best of talented employees. Some authors focus on the talent management as a success factor of organizational performance (Abbasi et al., 2010, p. 75; Raman et al., 2013, p. 341; Anwar et al., 2014, p. 1148; Namusonge et al., 2014, p. 52; Ingram, 2016, p. 201; Uddin et al., 2016, p. 16; Devi, 2017, p. 22), others study drivers of talent management adoption (Iles et al., 2010, p. 182; Sidani et al., 2014, p. 221) or talent management impact on employee engagement (Sadeli, 2015, p. 11; Mohammed, 2016, p. 144; Ali et al., 2019, p. 63; Friday et al., 2019, p. 7). Except these main research focuses we can also identify many other approaches to talent management such as: organizational justice (Gelens et al., 2013, p. 347), succession planning (Ahmadi et al., 2012, p. 213), talent management in research organizations (Gagné, 2011, p. 14; Březinová and Průšová, 2014, p. 151; Bradley, 2016, p. 14; Dabija et al., 2017, p. 537; El Masri et al., 2019, p. 133), and talent management within globalization (Collings, 2014, p. 308; Collings et al., 2019, p. 551). Most of researchers recognize five main phases of the talent management process (Zhang and Bright, 2012, p. 144; Tansley and Tietze, 2013, p. 1801; Schieman, 2014; Thunnissen et al., 2015, p. 191): planning, attracting, assessment, developing and retaining. Each of these phases was a subject of the theory (Hughes et al., 2008, p. 752; Bethke-Langenegger et al., 2011, p. 530; Coulson-Thomas, 2012, p. 431).

Nevertheless, only few researchers analyse the impact of talent management phases on the development of the organizational performance within an organization (Thunnissen et al., 2013, p. 331; Collings, 2014, p. 307; Omotunde and 
Alegbeleye, 2021). To fill this gap, the aim of the study is to find out whether all phases of the talent management process equally affect organizational results. The motive is to find the most important phases of talent management, which most significantly affect the results and therefore, which managers should focus more on in order to be able to improve organizational performance. Efficiency and effectiveness are crucial in the organizational performance and therefore we focus on the variable importance of each phase in order to attain organizational goals with limited resources or limited time. Despite the large quantity of earlier research on talent management, there is a paucity of work examining and comparing the added value of all phases in the talent management to the organizational performance. Moreover, to the best of our knowledge, there are no studies focusing on the role of talent management in the change of organizational performance of organizations in the Central and Eastern Europe.

We must emphasize that the research was carried out at a time when the business world was not affected by the current COVID situation. It is understandable that COVID has also slightly changed managerial behaviour towards the talent management. According to our observations and occasional interviews with managers, small and medium organizations try to reduce talent programs and cut their budgets, while larger organizations with foreign capital use talented people from the whole EU for their teleworking. In any case, it is necessary to pay attention to the individual phases of talent management even during crisis, because as our results prove, they can contribute to the improvement of organizational results in the post COVID period. However, we can already see only 8 studies in the WOS database researching talent management during the Covid-19 pandemics from diverse perspectives (Aguinis and Burgi-Tian, 2021; Mey et al., 2021; Vecchi et al., 2021; Tomcikova et al., 2021), but none of them analyse phases of talent management linked to organizational performance.

The rest of the paper is structured as follows: first, a literature review on the individual phases of the talent management process, then a conceptual framework in the methodological part including the sample, operationalization of variables and analytical methods followed by results and discussion. In the conclusion, we present some theoretical and practical implications.

\section{Literature Review}

\subsection{Talent Management Phases from Strategical Perspective}

Business environment is influenced by many new technological, social, economic, political, and demographic factors. Organisations operate in dynamic environment and a transformation of processes is needed in order to survive 
(Oreg et al., 2018, p. 75; Wee et al., 2018, p. 4). Successful companies usually react very flexibly to these environmental changes.

Although flexibility is supported with implementation of high-tech development and artificial intelligencehuman resources are still considered the key element in the process of changes (Zheltoukhova, 2014, p. 38). Talented and engaged employees move the company forward and bring added value. Currently, in many developed countries (Slovakia included) companies face lack of skilled labour and right people in the right positions. HRM is the mean to achieve organizational high performance. Talent management has become a priority for modern organizations (Beheshtifar et al., 2012, p. 230). It plays strategic role in each company (Alruwaili, 2018, p. 98), and it is the key factor to human capital development (Rudito et al., 2015, p. 1065). The talent of individual employees is a unique source of competitive advantage and involves a central element of strategic human resources policy in recent years (Frank, 2004, p. 37; Garavan et al., 2012, p. 35; Březinová and Průšová, 2014). Talent management is an espoused and enacted commitment to implementing an integrated, strategic and technology enabled approach to HRM (Hughes et al., 2008, p. 752). Careful deployment of talent management in the process of business strategy implementation may bring high economic value (Järvi et al., 2020, p. 81). Heinen et al. (2004), Bethke-Langenegger et al. (2011), Ingram (2016), Almohtaseb et al. (2020, p. 12), and Hongal et al. (2020, p. 66) focused their studies on the assessment of talent management strategy affecting organizational results and revealed that it significantly contributes to organizational performance.

Adopting talent management approach helps to face several important challenges: leadership development, workforce training, adapting innovations, compensation policy and benefits, workplace diversity, recruiting and retaining talented employees. While talent management is implemented in many companies in various ways (Pauli et al., 2019, p. 207), talented employees remain valuable and unique resource that makes valuable contributions in achieving organization's objectives (Collings et al., 2009, p. 308; Meyers et al., 2013, p. 313; Mihalcea, 2017, p. 301). Silzer et al., 2009, p. 115) connect HR strategy with key activities in talent management process to achieve strategic objectives and meet future business needs. Effective and efficient HR strategy is a good way to prevent lot of problems. Operational strategies for human resources can also improve performance (Bourne et al., 2003, p. 944). Talent management system positively influences a firm's ability to exploit knowledge and has an indirect positive effect on the company's performance through its absorptive capacity (Latukha et al., 2019, p. 506). The benefits of an effectively implemented talent management strategy include improved employee recruitment and retention rates, as well as 
enhanced employee engagement. These outcomes have been associated with higher operational and financial performance (Hughes et al., 2008, p. 752). There are also other benefits for companies that use talent management, including higher creativity connecting with business goals: valuable staff, career development, job satisfaction and faster reaction to changes. We can summarize that talent management is not only a fashionable HR topic, but it is crucial to business success (Collings et al., 2019, p. 552).

Organizational and talent management strategy is followed by identification of talents that is a step that has a limited impact on employee attitudes (Bjorkman et al., 2013). This second phase of the talent management is grounded on an identification of key positions and it is considered critical when filling key positions in the organization (Collings et al., 2019, p. 549). It refers to the process by which an organization identifies employees who are potentially able to move into the leadership roles in the future (Jerusalim and Hausdorf, 2007). Identification is tightly connected with assessment resulting to the recruitment.

Perrin (2005, p. 28) identified following factors as recruitment drivers: competitive base pay, work/life balance, carrier advancement opportunities, competitive benefits, challenging work, salary increase linked to the individual performance, learning and development opportunities, competitive retirement benefits, the calibre of co-workers and the reputation of the organization as a good employer. In talent management, recruiters tend to source the best candidates possible from their future perspective. According to Olsen (2000, p. 24), traditional departments oriented to recruit people have to be transformed to human talent attraction and retention departments. Recruitment activities might be the most important step to acquire talents when building a competitive advantage (Banks et al., 2019, p. 485). Talent development that follows the recruitment plays a crucial role in organizational performance and it also significantly influences organizational results (Latukha, 2018, p. 56; Omotunde and Alegbeleye, 2021).

Retention as the last phase in talent management process is also very significant. It is essential to have the best and the most talented employees, but it is equally necessary to be able to retain them for future purposes of the organisation (Kulkarni et al., 2019, p. 1881). Talent retention plays also a key role in the organizational performance (Lyria et al., 2017, p. 22; Holland et al., 2019, p. 22). Awards, recognition systems, and flexible working hours are considered successful determinants for talent retention (Obliopas et al., 2019, p. 3). Other factors that lead to high retention of talents include employee engagement and job satisfaction (Akila et al., 2014, p. 113) and leadership in the organization (Brunelli et al., 2019, p. 462). Retention remains also highly important during Covid-19 pandemics as a tool that helps increasing organizational performance (Aguinis and Burgi-Tian, 2021). 


\subsection{Impact of Talent Management Process on the Organizational Performance}

Organizational performance is a dynamic concept and it is the synergy of financial and nonfinancial factors Bhatti et al. (2014, p. 3131) which help to identify on which level of objectives and results are achieved (Lebas et al., 2002, p. 71). Numerous variables may determine, mediate or moderate relationships between constructs in organizational studies and authors have approached organizational performance from different perspectives. Talent management affects both work engagement and organizational citizenship behaviours, which consequently affect customer satisfaction (Kuntonbutr and Sangperm, 2019). Sun et al. (2019, p. 22) analysed roles of dynamic capabilities and knowledge management strategies on organizational performance. Bhatti et al. (2014, p. 3131) analysed the impact of KPIs on the organizational performance, but he did not mention the talent management process. Alrowwad et al. (2020, p. 202) investigated the impact of leadership styles, intellectual capital, and innovation on organization performance and revealed that intellectual capital and innovation played mediating roles in organizational performance. The link between talent management and personality traits were a centre of study by Lenz et al. (2020) who revealed that self-confidence is a consistent driver of overall performance, with resilience and job-specific creativity being essential in order to perform above peer-group level. According to Chakraborty et al. (2020, p. 69), human resource planning activities (job analysis and design, training, development, succession planning, and retention plan) affect the organizational performance. While recruitment plan has a negative and non-significant impact, the succession planning positively influences firm's competitive ability. Jasim (2020, p. 32) discovered that HRM practices (training and development) have a positive and significant effect on the organizational performance. The study of Rahimpour et al. (2020, p. 1491) focused on allocation of organizational resources in order to improve the organizational performance and showed that employee loyalty had a strong impact on intellectual capital and HRM. Talent analytics and strategic HRM lead to developing a high-performing talent pool, which contributes to organizational performance (Sivathanu et al., 2019, p. 462). A climate that supports creativity enables high organizational performance through talent management (Ingram, 2016, p. 201). Talent is considered as a crucial factor resulting in high performance (Harvey et al., 2002, p. 751; Hughes et al., 2008, p. 752).

Some studies are cross-industrial (Collings, 2014, p. 308), some are crosscultural (Dastmalchian et al., 2018, p. 15721) but others concentrate on particular sectors or specific groups (e.g., Namusonge et al., 2014, p. 52; Uddin et al., 2016, p. 16; Nasir et al., 2017, p. 35) or focus on case studies (e.g., Singh et al., 
2012, p. 97; Kim et al., 2014, p. 101). Organization should have the ability and capacity to recognize the people and the capability that may create value and deliver the competitive advantage for the organization (Rabbi et al., 2015, p. 211).

When talent practices can build and sustain capabilities of strategy, structure, culture and execution, then talent management can help to improve organizational performance (Joyce et al., 2012, p. 186). In particular, talented employees contribute significantly to the successful organizational performance (Dries et al., 2012, p. 274). By adopting appropriate talent management strategies, organisation can significantly increase its efficiency. Talent management process plays a key role in the organisation's performance (Lotfi et al., 2020, p. 72). While most of researches deal with assessing the impact of talent management as a whole on the performance of the organization (Joyce et al., 2012, p. 186), few studies focus on individual parts of talent management (e.g. Almohtaseb et al., 2020, p. 12; Hongal et al., 2020, p. 66; Ingram, 2016, p. 201; Bethke-Langenegger et al., 2011, p. 531; Heinen et al., 2004, p. 67) and rare studies analyse all phases of talent management from several points of view (Tlaiss, 2021). Our research is about to fill this gap by revealing the link between all talent management phases and the organisational performance.

\section{Data and Methods}

\subsection{Data}

Data were collected using a questionnaire, which was a follow-up to the questionnaire used in previous studies (Egerová et al., 2015, p. 112) the authors co-authored. The questionnaire consisted of a) general questions designed to characterize the respondent and the organization in which the respondent works and b) items of the questionnaire divided into five parts, which corresponded to the individual phases of the talent management process. The questionnaire was distributed in an electronic form. There were 381 Slovak organizations taking part in the conducted survey, each representing one organisation. The data collection took place from July 2018 to October 2018. In order to generalize the results, it was necessary to set the research sample to correspond as much as possible with the target group. As it was not possible to make a random sample, quota selection was used to ensure that the research sample was representative. With the help of quota selection, it is thus possible to secure respondents who meet the set criteria. The research sample in this study reflects the distribution of the whole set of enterprises according to criteria such as enterprise size, ownership and foreign capital participation. Respondents in our research were selected 
and consulted with a research agency, which ensured a sufficient representative number of respondents in each category. They were then contacted via e-mail and given a questionnaire online. Each respondent represents one organization. Representatives were mostly people responsible for the HR development in the organization. Only organizations that at least partially showed indications of talent management in their organization were included into the analysis, even though they did not have human resources departments.

We observed several characteristics of organizations. The size of the organization was expressed by the number of its employees. Micro-enterprises were excluded from the research sample. Small enterprises accounted for the most numerous group (47.51\%) in the research sample. The representation of medium and large enterprises was relatively balanced. The dominant form of ownership was private ownership, with state-owned organizations accounting for less than $9 \%$ of all organizations surveyed. In terms of the representation of foreign capital in the capital structure of organizations, most organizations were owned by domestic owners and a total of $42 \%$ of organizations were owned by foreign investors. Compared to the previous year, the economic situation in the vast majority of organizations was either better or stabilized. Less than $10 \%$ of organizations declared its worsening. Almost two thirds of organizations have established HR departments in their organizational structure (Table 1).

T a b l e 1

Characteristics of the Research Sample (in \%)

\begin{tabular}{|l|c|l|r|l|l|l|r|r|c|}
\hline \multicolumn{2}{|l|}{ Size } & \multicolumn{2}{|c|}{ Ownership } & \multicolumn{2}{c|}{ Capital } & \multicolumn{2}{c|}{ Org. performance } & \multicolumn{2}{c|}{ Hr department } \\
\hline Small & 47.51 & Private & 91.07 & Foreign & 41.73 & Improved & 48.29 & Yes & 62.20 \\
Medium & 29.66 & State owned & 8.66 & Domestic & 57.74 & The same & 41.73 & No & 37.53 \\
Large & 22.31 & & & & & Worsened & 9.17 & & \\
\hline
\end{tabular}

Source: Own processing.

T a b 1 e 2

Operationalisation of the Variables

\begin{tabular}{|c|c|c|}
\hline Variable & Coding & Measurement \\
\hline $\begin{array}{l}\text { Change of organizational performance } \\
\text { of a company in terms of profit } \\
\text { (when compared to previous year) }\end{array}$ & ORG_PER & 1 -improved; 2 - the same; 3 - worsened \\
\hline Strategy (Planning) & TM_PH1 & $\begin{array}{l}\text { Average score for items } 1 \text { to } 9 \\
\text { Likert scale: } 1 \text { - totally agree; } 5 \text { - totally disagree }\end{array}$ \\
\hline Identification (Attracting) & TM_PH2 & $\begin{array}{l}\text { Average score for items } 10 \text { to } 20 \\
\text { Likert scale: } 1 \text { - totally agree; } 5 \text { - totally disagree }\end{array}$ \\
\hline Assessment & TM_PH3 & $\begin{array}{l}\text { Average score for items } 21 \text { to } 27 \\
\text { Likert scale: } 1 \text { - totally agree; } 5 \text { - totally disagree }\end{array}$ \\
\hline Development & TM_PH4 & $\begin{array}{l}\text { Average score for items } 28 \text { to } 34 \\
\text { Likert scale: } 1 \text { - totally agree; } 5 \text { - totally disagree }\end{array}$ \\
\hline Retention & TM_PH5 & $\begin{array}{l}\text { Average score for items } 35 \text { to } 41 \\
\text { Likert scale: } 1 \text { - totally agree; } 5 \text { - totally disagree }\end{array}$ \\
\hline
\end{tabular}

Source: Own processing. 
Based on the average score of respondents' attitudes five synthetizing variables (TM_PH1-5) were constructed. The operationalisation of the variables is shown in Table 2.

The questionnaire items $1-9$ dealing with the strategy (TM_PH1) focused on the implementation of talent management into HR processes and overall strategy of an organization. They also inquired about the manager attitudes towards talent management and their perception of its importance. The questionnaire items $10-20$ were focused on the identification phase of the talent management process (TM_PH2). The items dealt with the talent attraction, adopting of inclusive and exclusive talent management approach, processes of talent identification and with predicting of future needs of talented individuals. Items $21-27$ focused on the ways the talented employees are assessed (TM_PH3) in organizations and how is this phase of talent management process linked with the reward system. Items 28 - 34 dealt with the development phase (TM_PH4). They focused on the methods and results of the talent development as well as on the financial and time aspects of this phase of the talent management process. The questionnaire items $35-41$ were focused on the retention of talented employees, communication strategies with the talented individuals and support strategies of their self-improvement.

\subsection{Methods}

The reliability of the questionnaire was verified by means of Cronbach's alpha. Regarding the achieved results, it is therefore possible to regard the reliability of the measurement instrument as sufficient (Table 3).

T a b le 3

Reliability Evaluation

\begin{tabular}{|l|c|c|}
\hline Variable & Number of Items & Cronbach s Alpha \\
\hline TM_PH1 (Strategy) & 9 & 0.851 \\
TM_PH2 (Identification) & 11 & 0.777 \\
TM_PH3 (Assessment) & 7 & 0.720 \\
TM_PH4 (Developing) & 7 & 0.801 \\
TM_PH5 (Retaining) & 7 & 0.743 \\
\hline
\end{tabular}

Source: Own processing.

The construct validity was verified by means of factor analysis using the varimax rotation of factors. It is the most commonly used method for rotation procedure. Varimax rotation of factors is an orthogonal method of rotation that minimises the number of variables with high loadings on a factor, thereby enhancing the interpretability of the factors (Abdi, 2003, p. 792). The suitability of applying the factor analysis was verified based on Kaiser-Meyer-Olkin Measure 
of Sampling Adequacy (KMO test) and Bartlett's test of sphericity. The results of both testing statistical methods were satisfactory (Bartlett's test: $\mathrm{p}<0.05$; KMO test $>0.7(0.866))$. The assumptions of applying the factor analysis were met. The factor analysis identified 5 background factors which altogether explained almost $70 \%$ of the total variance $(68.48 \%)$. Based on the fact the correlating questionnaire items corresponded with the questionnaire's content (talent management phases), we regard the construction validity of the measurement instrument satisfactory.

To evaluate the influence of the individual phases of the talent management process (independent variables) the linear regression was used. The dependent variable is the change of organizational performance (ORG_PER) of a company (in terms of profit) when compared to previous year. Independent variables are strategy (TM_PH1); identification (TM_PH2); assessment (TM_PH3); development (TM_PH4) and retention (TM_PH5). The functional form of regression is as follows:

$$
\begin{aligned}
& O R G_{-} P E R=\beta_{0}+\beta_{1} T M_{-} P H 1+\beta_{2} T M_{-} P H 2+\beta_{3} T M_{-} P H 3+ \\
& +\beta_{4} T M_{-} P H 4+\beta_{5} T M_{-} P H 5+\varepsilon
\end{aligned}
$$

The tested model is shown in Figure 1. We evaluated the impact of individual phases of the talent management process on the overall organizational performance and their individual impact on its development. Based on the previous text we tested following research hypotheses:

H1: The individual phases of the talent management process are equally important with respect to overall organizational performance.

H2: The individual phases of the talent management process are equally important when the development of the organizational performance considered.

Fig u r e 1

\section{Research Model}

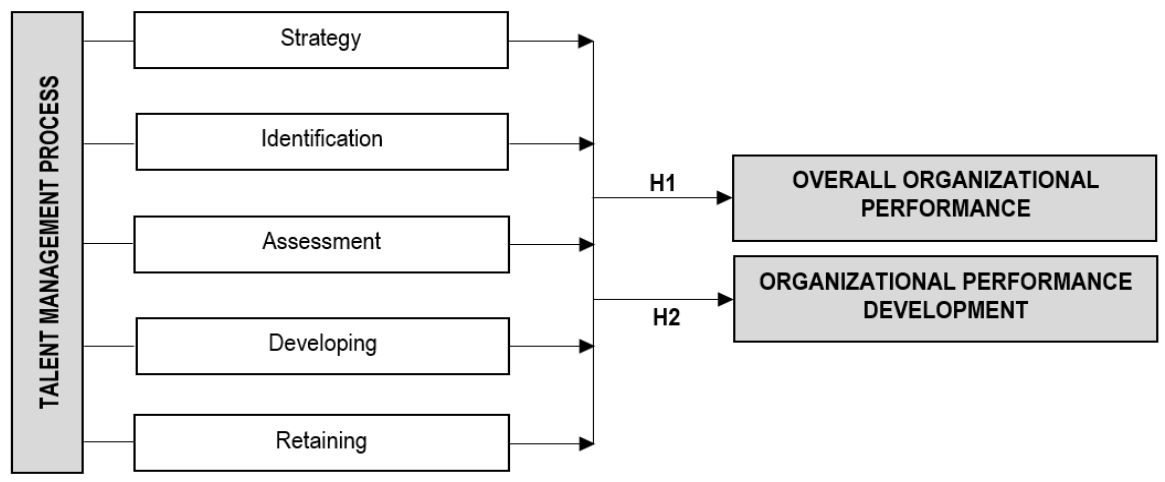

Source: Own processing. 
To evaluate the statistical significance of the differences in realization of talent management process in companies with different development of their organizational performance ANOVA was used. To further explain these differences the focus group approach was utilized. The Focus Group as a qualitative research method based on discussion in the group is used to obtain data and views of participants that are more difficult to reach outside the group (Bloor and Wood, 2006, p. 121). The focus groups were constructed to ascertain certain differences in perception of talent management phases on organizational performance. The focus groups were constructed with respect to the development of the organizational performance in the organization. There were formed three focus groups (one for each type of development) and the size of a focus group varied between $5-7$ (O. Nyumba et al., 2018, p. 26).

\section{Results}

In Figure 2, organizations' attitudes to the individual phases of the talent management process depending on the evolution of their organizational performance can be observed. A higher average score means that organizations have expressed a less positive attitude towards the individual talent management activities. The highest average score in each phase (strategy, identification, assessment, developing, retaining) was achieved by organizations whose organizational performance deteriorated compared to the previous year.

Figure 2

Talent Management Process Phases and Organizational Performance Change
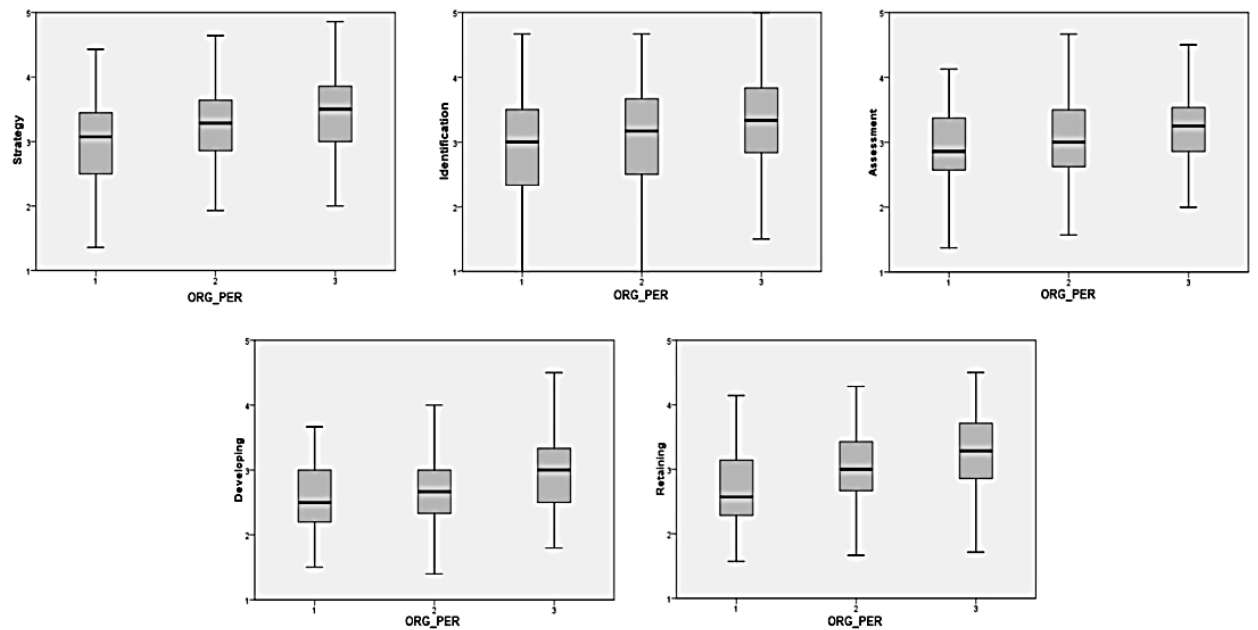

Note: y axis: 1 - totally agree, 5 - totally disagree; $x$ axis: 1 -improved, 2 - the same, 3 - worsened. Source: Own processing. 
To assess the relationship between the change of the organizational performance of the organizations and the individual phases of the talent management process a linear regression model was used. The dependent variable was the change of the organizational performance (ORG_PER) and the independent variables were the individual phases of the talent management process (strategy (TM_PH1), identification (TM_PH2), assessment (TM_PH3), developing (TM_PH4) and retaining (TM_PH5)). We assumed that all talent management phases will significantly affect the development of the organizational performance; that is, they will be equally important. Based on the results, however, we conclude that the three phases of the talent management process (strategy, identification and assessment) do not have a statistically significant impact on the development of the organizational performance in the organization. The other two phases (developing and retaining) do (Table 4). When comparing the importance of the individual phases of talent management process (Table 4), retaining (TM_PH5) seems to be the most important phase, followed by developing (TM_PH4). The Standardized Beta value of retaining (TM_PH5) is slightly higher than that of development (TM_PH4). Assessment (TM_PH3) and strategy (TM_PH1) seem to be equally important. The least important talent management phase seems to be identification (TM_PH1).

Table 4

Impact of the Talent Management Phases on the Organizational Performance

\begin{tabular}{|l|c|c|c|l|}
\hline Variable & Unstandardized B & Standardized Beta & t & p level \\
\hline (Constant) & 1.046 & & 5.063 & $0.000 * * *$ \\
TM_PH1 (Strategy) & 0.053 & 0.051 & 0.658 & 0.511 \\
TM_PH2 (Identification) & 0.018 & 0.021 & 0.283 & 0.777 \\
TM_PH3 (Assessment) & 0.052 & 0.050 & 0.720 & 0.472 \\
TM_PH4 (Development) & 0.183 & 0.161 & 2.863 & $\mathbf{0 . 0 0 4} * *$ \\
TM_PH5 (Retention) & 0.179 & 0.170 & 2.726 & $\mathbf{0 . 0 0 7} * *$ \\
\hline
\end{tabular}

Note: $* * * \mathrm{p}<0.001 ; * * \mathrm{p}<0.01 ; * \mathrm{p}<0.05$.

Source: Own processing.

We were interested among which groups of organizations (based on the development of their organizational performance) there were statistically significant differences. We use HSD test for unequal $\mathrm{N}$ for multiple comparisons. For the first three phases of the talent management process (strategy, identification, assessment) tests identified two homogeneous groups of organizations. The first group consisted of organizations in which the economic situation deteriorated compared to the previous year. The second group consisted of organizations with a stable or improving organizational performance. 
Thus, in the perception of the first part of the talent management process, organizations with a good organizational performance differ from organizations in which the organizational performance worsens (Table 5).

For the final stages of the talent management process (developing, retaining), tests identified three homogeneous groups. There was a difference between all groups of organizations based on the development of their organizational performance. The organizations with an improving organizational performance expressed a more favourable attitude (lower average score) towards the talent management activities than organizations with a stabilized organizational performance. They in turn expressed a more favourable attitude compared to organizations where the organizational performance deteriorated.

Based on these findings, it can be concluded that the companies whose organizational performance has improved have been able to not only develop further the skills of the most talented employees, but also successfully retain talented employees (Table 5).

Table 5

\section{PostHoc Test Results}

\begin{tabular}{|c|c|c|c|c|c|c|c|c|c|c|c|c|}
\hline & \multicolumn{2}{|c|}{ Strategy } & \multicolumn{2}{|c|}{ Identification } & \multicolumn{2}{|c|}{ Assessment } & \multicolumn{3}{|c|}{ Development } & \multicolumn{3}{|c|}{ Retention } \\
\hline Org. performance & 1 & 2 & 1 & 2 & 1 & 2 & 1 & 2 & 3 & 1 & 2 & 3 \\
\hline Worsened & $\mathrm{xxxx}$ & & $\mathrm{xxxx}$ & & $\mathrm{xxxx}$ & & $\mathrm{xxxx}$ & & & $\mathrm{xxxx}$ & & \\
\hline $\begin{array}{l}\text { The Same } \\
\text { Improved }\end{array}$ & & $\begin{array}{l}x x x x \\
x x x x\end{array}$ & & $\begin{array}{l}\mathrm{xxxx} \\
\mathrm{xxxx}\end{array}$ & & $\begin{array}{l}x x x x \\
x x x x\end{array}$ & & $\mathrm{xxxx}$ & $\mathrm{xxxx}$ & & $\mathrm{xxxx}$ & $\mathrm{xxxx}$ \\
\hline
\end{tabular}

Source: Own processing.

Based on the results, there are several statistically significant differences in talent management process realization explaining why companies with improved organizational performance achieved better results (Table 6).

In the focus group sessions, companies with improved organizational performance indicate the following differences:

A. In the strategy (TM_PH1), the top management has a positive attitude towards talent management and HR strategy is clearly defined. Top management considers talent management extremely important for results and therefore it is apart of company's mission.

These companies have the talent management strategy defined and it is usually highly connected with strategic goals of the company. People responsible for HR strategy usually modify the list of key talents indispensable for organizations in accord with the changing outside conditions. They also try to search for talent in every single employee and are of opinion that the formulated talent management strategy is not difficult to realize in their organization. 
B. In the phase of identification (TM_PH2), successful companies adopt an inclusive talent management approach and identify talents among all the employees. They believe there is a talent hidden in everyone to some extent. Companies with improved organizational performance are willing to spend more money for improvement of the system of recruitment. That in turn enables to acquire people with the highest development potential.

These companies are usually more attractive for talented people and one of the logical consequences is an ability to afford much better rewards for talented individuals. Therefore, talented people are willing to get employed by these companies.

C. In the phase of assessment (TM_PH3), companies with improved organizational performance usually systematically assess employees' performance. The talent management system is linked to employees' reward system.

These organizations adopt promotion system based on the objective criteria which are put in place by the commission in charge of HR development. These criteria are broadly communicated and well known to all employees. The results of assessment process are used to formulate individual talent development plans.

D. As for the development (TM_PH4), successful companies use a wide range of forms and methods of employees' competences development when compared to the less successful companies. They have better possibilities to allocate available resources into development programmes resulting in competences improvement. According to our research, in companies with improved organizational performance, there is a well-formulated system of career paths for talented employees and therefore there is better possibility to develop talents.

Those organizations are strongly focusing on planning of individual development activities for talents. Managers of these companies are allowed enough time to develop employees' competences and all these development activities usually have a strong financial support by the top management of the organization.

E. All these facts contribute to better conditions for successful retention (TM_PH5) of talented individuals in the companies with improved organizational performance.

These companies can meet financial requirements of talented people much better when compared to other companies. They are also able to retain talented individuals by supporting them in their self-improvement process. Also, a fair and functioning system of motivation plays an important role in the successful retention of talents in companies with improved organizational performance. 


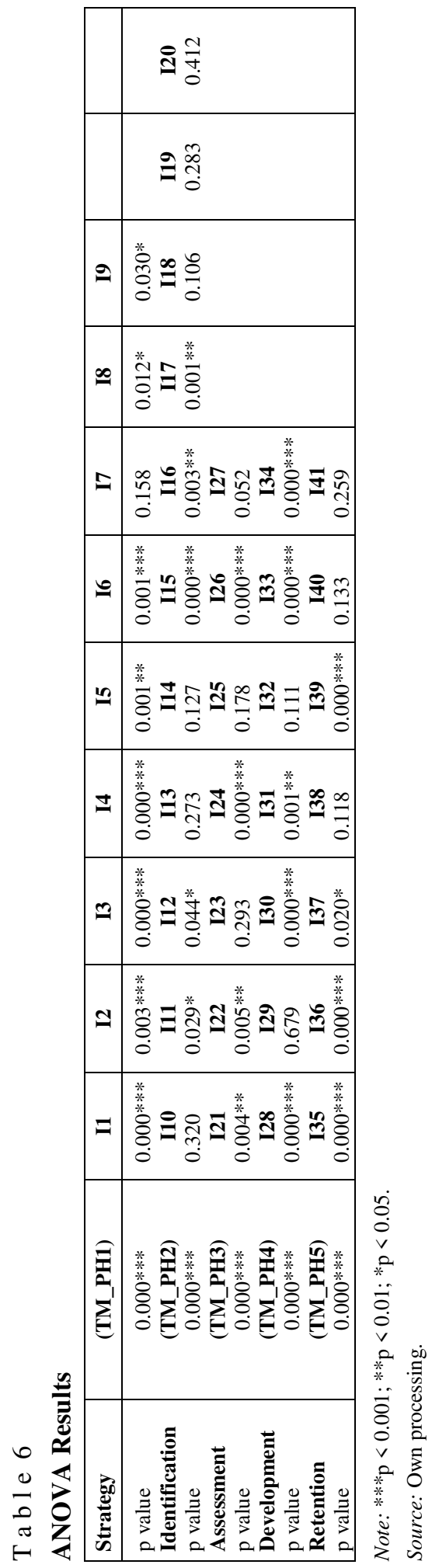




\section{Discussion}

Usually, a strategic vision is required to identify, develop, maintain, and renew the talented employees and their key capabilities in the organization in relation to the external environment characterized by challenges of the competition and the war for talent. In this study, we evaluate organizational performance based on financial indicators and clarify the relation between talent management stages and organizational performance. Research results bring support to existing discussion related to links between talent management and organizational performance. They support claims that the organizational ability in managing talents influences organizational performance (Levenson, 2012, p. 189; Devi, 2017, p. 14; Collings et al., 2019, p. 559).

The most important phase of the talent management process seems to be the retention of the talented employees. These results are in line with several previous studies stressing the retention as one of the key success factors in adopting the talent management approach (Oladapo, 2014, p. 27; Rabbi et al., 2015, p. 211; Tafti et al., 2017, p. 17). Successful retention of talent is also one of the ways how to maintain competitiveness of organizations (Hughes and Rog, 2008, p. 752).

Based on the results, the least important phase of the talent management process with respect to the organizational performance seems to be the talent identification phase. This finding is in line with several studies focusing on the importance of developing of talents (Gagné, 2011, p. 17; Garavan et al., 2012, p. 33; Saar, 2013, p. 8; Aziz et al., 2016, p. 3) and their retention (Hughes, et al., 2008, p. 752; Akila et al., 2014, p. 118; Oladapo, 2014, p. 27; Kulkarni et al., 2019, p. 1881). On the other hand, there are studies stressing the importance of the talent identification especially in the context of sustainable development of an organization (Wiblen, 2016, p. 96; McDonnell et al., 2017, p. 93; Hsieh et al., 2019, p. 1452).

Results also suggest that the relationship between the effective talent management and organizational performance goes both ways, that the good performing organizations are not only able retain their talented employees, but they are also able to further develop their skills. This result correspondents with those of several studies focusing on the importance of talent development (Garavan et al., 2012, p. 33; Saar, 2013, p. 8; Meyers et al., 2013, p. 313; Khilji et al., 2015, p. 241; Krishnan et al., 2017, p. 435).

\section{Conclusion}

This study sheds light on the dependence between organizational performance that was measured based on financial indicators and different talent management phases in order to point out a diverse importance of these phases. It 
theoretically contributes to a better understanding of the importance of all talent management phases that support organizational performance. The results discovered that all talent management phases differently impact the organizational performance. While the strategy, talent identification and assessment seem to have no impact on organizational performance, talent development and talent retention significantly influence the progress of the organizational performance. The results are widely applicable, especially in countries of the Central and Eastern Europe. Study results should be useful for decision makers on all managerial levels in practical view on the contribution of talent management phases on organizational performance as well as for researchers in future research orientation. Specifically, study deals with the relationship between the different phases of the talent management process and the change of the organizational performance. This relationship is of course two-way, as the successful implementation of talent management activities on the one hand affects the development (also economic) in the organization, but on the other hand, this development affects the way and focus of talent management activities. Authors focused on the influence of talent management on the development of organizational performance and evaluation of the impact of its individual phases.

As for practical implications, the results offer several policy implications for decision makers. They show that not all phases of the talent management process are equally important in relation to the development of the organizational performance. Research has identified that development and retention are more important than strategy (planning), identification (attracting) and assessment. Retaining talents seems to be the most important phase of the process while the least important phase is the talent identification that might be a result of previous investments into HR. Based on these facts, we suggest to organizations invest the most resources into employee retention and the least into attracting and planning. Even if this result might be contextual, it implies several recommendations for decision makers. Strategy of stabilization or enhancement of the organizational performance requires the focus on the development and retaining of talented employees. Specific policies will of course vary depending on the type of organization. Large organizations and SMEs will do otherwise. Branches of foreign companies with experience in talent management when compared to domestic organizations apply different approaches. Even if the identification of talented individuals seems to have a lesser impact on the change of organizational performance it cannot be neglected. Based on our experiences, its importance would be more recognized in the longer term.

While this study provides useful findings contributing to the topic of talent management and organizational performance, it also has the limitations that call for further research. The research was carried out at a time when not only Slovakia, 
but also the whole EU was doing well, so the ratio of organizations with stabilized or improving organizational performance was high. In times of recession, organizations' views on the importance of the individual phases of the talent management process could be different. Therefore, future research could be carried out at a time when the negative economic consequences of the current crisis caused by the COVID-19 pandemic appear. It would also be desirable to increase the number of organizations examined and to apply stratification not only by size and by form of ownership and capital structure, but also by industry they operate in and the time since their establishing. We also recommend analysing talent management in virtually organized organizations and organizations heavily relying on teleworking. The last suggestion for future research is to conduct the research in the broader time frame in order to use a panel data approach.

\section{References}

ABBASI, M. U. - SOHAIL, M. - SYED, N. (2010): Talent Management as Success Factor for Organizational Performance: A Case of Pharmaceutical Industry in Pakistan. IBT Journal of business studies, 6 , No. 2, pp. $74-83$.

ABDI, H. (2003): Factor Rotations in Factor Analyses. Encyclopedia for Research Methods for the Social Sciences. Thousand Oaks, CA: Sage, pp. $792-795$.

AGUINIS, H. - BURGI-TIAN, J. (2021): Talent Management Challenges during COVID-19 and Beyond: Performance Management to the Rescue. BRQ Business Research Quarterly, 23409444211009528. Available at: <https://doi.org/10.1177/23409444211009528>.

AHMADI, A. A. - AHMADI, F. - ABBASPALANGI, J. (2012): Talent Management and Succession Planning. Interdisciplinary Journal of Contemporary Research in Business, 4, No. 1, pp. $213-224$.

AKILA, R. - PAMAVATHY, N. (2014): Employee Talent Retention Using Employee Engagement and Job Satisfaction at HCL Technologies Oserv. Division Chennai. Zenith International Journal of Business Economics and Management Research, 4, No. 7, pp. 113 - 120.

ALI, Z. - BASHIR, M. - MEHREEN, A. (2019): Managing Organizational Effectiveness through Talent Management and Career Development: The Mediating Role of Employee Engagement. Journal of Management Sciences, 6, No. 1, pp. $62-78$. Available at: <https://doi.org/10.20547/jms.2014.1906105>.

ALMOHTASEB, A. A. - SHAHEEN, H. A. K. - ALOMARI, K. M. - YOUSEF, M. A. (2020): Impact of Talent Management on Organizational Performance: The Moderating Role of an Effective Performance Management System. International Journal of Business and Management, 15, No. 4, pp. 11 - 24. DOI: 10.2139/ssrn.3948559.

ALROWWAD, A. A. - ABUALOUSH, S. H. (2020): Innovation and Intellectual Capital as Intermediary Variables among Transformational Leadership, Transactional Leadership, and Organizational Performance. Journal of Management Development, 39, No. 2, pp. 196 - 222. Available at: 〈https://doi.org/10.1108/JMD-02-2019-0062〉.

ALRUWAILI, N. F. (2018): Talent Management and Talent Building in Upgrading Employee Performance. European Journal of Sustainable Development, 7, No. 1, pp. 98 - 98. Available at: <https://doi.org/10.14207/ejsd.2018.v7n1p98>.

ANWAR, A. - NISAR, Q. A. - KHAN, N. Z. A. - SANA, A. (2014): Talent Management: Strategic Priority of Organizations. International Journal of Innovation and Applied Studies, 9, No. 3, pp. $1148-1154$. 
AZIZ, M. I. - AFTHANORHAN, A. - AWANG, Z. (2016): Talent Development Model for a Career in Islamic Banking Institutions: A SEM Approach. Cogent Business and Management, 3, No. 1, pp. 1 - 11. DOI: 10.1080/23311975.2016.1186259.

BANKS, G. C. - WOZNYJ, H. M. - WESSLEN, R. S. - FREAR, K. A. - BERKA, G. - HEGGESTAD, E. D. - GORDON, H. L. (2019): Strategic Recruitment across Borders: An Investigation of Multinational Enterprises. Journal of Management, 45, No. 2, pp. 476 - 509. DOI: $10.1177 / 0149206318764295$.

BHATTI, M. I. - AWAN, H. M. - RAZAQ, Z. (2014): The Key Performance Indicators (KPIs) and Their Impact on Overall Organizational Performance. Quality and Quantity, 48, No. 6, pp. 3127 - 3143. DOI: 10.1007/s11135-013-9945-y.

BEHESHTIFAR, M. - NASAB, H. Y. - MOGHADAM, M. N. (2012): Effective Talent Management: A Vital Strategy to Organizational Success. International Journal of Academic Research in Business and Social Sciences, 2, No. 12, pp. 227 - 334.

BETHKE-LANGENEGGER, P. - MAHLER, P. - STAFFELBACH, B. (2011): Effectiveness of Talent Management Strategies. European Journal of International Management, 5, No. 5, pp. $524-539$.

BLOOR, M. - WOOD, F. (2006): Keywords in Qualitative Methods. London: SAGE Publications, 204 p. ISBN 10-0-7619-4330-7. DOI: 10.1016/j.evalprogplan.2007.01.010.

BOURNE, M. - MILLS, J. - FAULL, N. (2003): Operations Strategy and Performance: A Resource-based Perspective. International Journal of Operations and Production Management, 23, No. 9, pp. 944 - 946. Available at: <https://doi.org/10.1108/01443570310491710>.

BRADLEY, A. P. (2016): Talent Management for Universities. Australian Universities' Review, 58 , No. 1 , pp. $13-19$.

BŘEZINOVÁ, M. - PRŮŠOVÁ, J. (2014): Small and Medium-sized Enterprises in Terms of Their Goals. Megatrend revija, 11, No. 3, pp. $145-154$.

BRUNELLI, M. - CAVAZOTTE, F. (2019): Responsible Leadership in Social Entrepreneurship: Understanding Challenges and Positive Performance Results. Academy of Management Global Proceedings, (2019), pp. $459-468$.

CHAKRABORTY, D. - BISWAS, W. (2020): Articulating the Value of Human Resource Planning (HRP) Activities in Augmenting Organizational Performance toward a Sustained Competitive Firm. Journal of Asia Business Studies, 14, No. 1, pp. 62 - 90. Available at: <https://doi.org/10.1108/JABS-01-2019-0025>.

COLLINGS, D. G. - MELLAHI, K. (2009): Strategic Talent Management: A Review and Research Agenda. Human Resource Management Review, 19, No. 4, pp. 304 - 313. Available at: <https://doi.org/10.1016/j.hrmr.2009.04.001>.

COLLINGS, D. G. (2014): Toward Mature Talent Management: Beyond Shareholder Value. Human Resource Development Quarterly, 25, No. 3, pp. 301 - 319. DOI: 10.1002/hrdq.21198.

COLLINGS, D. G. - MELLAHI, K. - CASCIO, W. F. (2019): Global Talent Management and Performance in Multinational Enterprises: A Multilevel Perspective. Journal of Management, 45, No. 2, pp. 540 - 566. Available at: <https://doi.org/10.1177/0149206318757018>.

COULSON-THOMAS, C. (2012): Talent Management and Building High Performance Organisations. Industrial and Commercial Training, 44, No. 7, pp. $429-436$. DOI: $10.1108 / 00197851211268027$.

DABIJA, D. C. - POSTELNICU, C. - DINU, V. - MIHĂILĂ, A. (2017): Stakeholders' Perception of Sustainability Orientation within a Major Romanian University. International Journal of Sustainability in Higher Education, 18, No. 2, pp. 533 - 553. Available at: $<$ https://doi.org/10.1108/IJSHE-10-2015-0169>.

DASTMALCHIAN, A. - BACON, N. - MCNEIL, N. - STEINKE, C. - BLYTON, P. - SATISH KUMAR, M. ... - CRAIG, T. (2018): High-performance Work Systems and Organizational Performance: The Role of Societal Culture. [Academy of Management Proceedings, 2019, No. 1, p. 15721.] Briarcliff Manor, NY: Academy of Management. 
DEVI, S. (2017): Impact of Talent Management on Organizational Performance: The Role of Employee Engagement. International Journal of Management Studies, 4, No. 1, pp. 17 - 27.

DRIES, N. - van ACKER, F. - VERBRUGGEN, M. (2012): How 'Boundaryless' Are the Careers of High Potentials, Key Experts and Average Performers? Journal of Vocational Behavior, 81, No. 2, pp. 271 - 279. DOI: 10.1016/j.jvb.2011.10.006.

EGEROVÁ, D. - LANČARIČ, D. - EGER, L. - SAVOV, R. (2015): Perspectives of Talent Management: Evidence from Czech and Slovak Business Organisations. Economics and Management, 18, No. 4, pp. 108 - 120. DOI: 10.15240/tul/001/2015-4-008.

EL MASRI, N. - SULIMAN, A. (2019): Talent Management, Employee Recognition and Performance in the Research Institutions. Studies in Business and Economics, 14, No. 1, pp. 127 - 140. DOI: 10.2478/sbe-2019-0010.

FRANK, F. D. - TAYLOR, C. R. (2004): Talent Management: Trends that will Shape the Future. Human Resource Planning, 27, No. 1, pp. $33-41$.

FRIDAY, E. O. - SUNDAY, M. (2019): Talent Management and Workers' Commitment. SEISENSE Journal of Management, 2, No. 3, pp. 1 - 15. Available at: <https://doi.org/10.33215/sjom.v2i3.138>.

GAGNÉ, F. (2011): Academic Talent Development and the Equity Issue in Gifted Education. Talent Development and Excellence, 3, No. 1, pp. 3-22.

GALLARDO-GALLARDO, E. - DRIES, N. - GONZÁLEZ-CRUZ, T. F. (2013): What is the Meaning of 'Talent' in the World of Work? Human Resource Management Review, 23, No. 4, pp. 290 - 300. Available at: <https://doi.org/10.1016/j.hrmr.2013.05.002>.

GARAVAN, T. N. - CARBERY, R. - ROCK, A. - NILSSON, S. - ELLSTRÖM, P. E. (2012): Employability and Talent Management: Challenges for HRD Practices. European Journal of Training and Development, 36, No. 1, pp. $26-45$. Available at: $<$ https://doi.org/10.1108/03090591211192610>.

GELENS, J. - DRIES, N. - HOFMANS, J. - PEPERMANS, R. (2013): The Role of Perceived Organizational Justice in Shaping the Outcomes of Talent Management: A Research Agenda. Human Resource Management Review, 23, No. 4, pp. 341 - 353. Available at: <https://doi.org/10.1016/j.hrmr.2013.05.005>.

HARVEY, J. - PETTIGREW, A. - FERLIE, E. (2002): The Determinants of Research Group Performance: Towards Mode 2? Journal of Management Studies, 39, No. 6, pp. $747-774$. Available at: <https://doi.org/10.1111/1467-6486.00310>.

HEINEN, J. S. - O’NEILL, C. (2004): Managing Talent to Maximize Performance. Employment Relations Today, 31, No. 2, p. 67.

HONGAL, P. - KINANGE, U. (2020): A Study on Talent Management and Its Impact on Organization Performance-an Empirical Review. International Journal of Engineering and Management Research, 10, No. 1, pp. 64 - 71. Available at: <https://doi.org/10.31033/ijemr.10.1.12〉.

HORVÁTHOVÁ, P. - VELČOVSKÁ, Š. - KAUEROVÁ, L. - LARSEN, F. R. (2020): Evaluation of Key Positions and Employees Management Level in Manufacturing Industry - The Czech Case. Sustainability, 12, No. 1, pp. 242 - 255. Available at: <https://doi.org/10.3390/su12010242>.

HOLLAND, D. - SCULLION, H. (2019): Towards a Talent Retention Model: Mapping the Building Blocks of the Psychological Contract to the Three Stages of the Acquisition Process. The International Journal of Human Resource Management, pp. 1 - 46. DOI: $10.1080 / 09585192.2019 .1569546$.

HSIEH, C. T. - HURST, E. - JONES, C. I. - KLENOW, P. J. (2019): The Allocation of Talent and US Economic Growth. Econometrica, 87, No. 5, pp. 1439 - 1474. Available at: <https://doi.org/10.3982/ECTA11427>.

HUGHES, J. C. - ROG, E. (2008): Talent Management: A Strategy for Improving Employee Recruitment, Retention and Engagement within Hospitality Organizations. International Journal of Contemporary Hospitality Management, 20, No. 7, pp. 743 - 757. Available at: <https://doi.org/10.1108/09596110810899086>. 
ILES, P. - CHUAI, X. - PREECE, D. (2010): Talent Management and HRM in Multinational Companies in Beijing: Definitions, Differences and Drivers. Journal of world Business, 45, No. 2, pp. 179 - 189. DOI: 10.1016/j.jwb.2009.09.014.

INGRAM, T. (2016): Relationships between Talent Management and Organizational Performance: The Role of Climate for Creativity. Entrepreneurial Business and Economics Review, 4, No. 3 , pp. 195 - 205. DOI: 10.15678/EBER.2016.040315.

JÄRVI, K. - KHOREVA, V. (2020): The Role of Talent Management in Strategic Renewal. Employee Relations: The International Journal, 42, No. 1, pp. $75-89$.

JASIM, S. S. (2020): Impact of Human Resource Management Practices on Enhancing Organizational Performance. Calitatea, 21, No. 174, pp. 28 - 34.

JOYCE, W. F. - SLOCUM, J. W. (2012): Top Management Talent, Strategic Capabilities, and Firm Performance. Organizational Dynamics, 41, No. 3, pp. 183 - 193. DOI: 10.1016/j.orgdyn.2012.03.001.

KHILJI, S. E. - TARIQUE, I. - SCHULER, R. S. (2015): Incorporating the Macro View in Global Talent Management. Human Resource Management Review, 25, No. 3, pp. 236 - 248. Available at: 〈https://doi.org/10.1016/j.hrmr.2015.04.001〉.

KIM, Y. - WILLIAMS, R. - ROTHWELL, W. J. - PENALOZA, P. (2014): A Strategic Model for Technical Talent Management: A Model Based on a Qualitative Case Study. Performance Improvement Quarterly, 26, No. 4, pp. 93 - 121. Available at: 〈https://doi.org/10.1002/piq.21159>.

KRISHNAN, T. N. - SCULLION, H. (2017): Talent Management and Dynamic View of Talent in Small and Medium Enterprises. Human Resource Management Review, 27, No. 3, pp. 431 - 441. Available at: 〈https://doi.org/10.1016/j.hrmr.2016.10.003〉.

KUNTONBUTR, C. - SANGPERM, N. (2019): Study on Talent Management Influence on Customer Satisfaction. Polish Journal of Management Studies, 20, No. 2, pp. 334 - 344. DOI: $10.17512 / \mathrm{pjms} .2019 .20 .2 .28$.

KULKARNI, M. A. - KOTHELKAR, A. A. (2019): A Study on Best Practices for Employee Retention and Commitment. Our Heritage, 67, No. 2, pp. 1877 - 1892.

LATUKHA, M. O. (2018): Talent Development and a Firm's Performance: Evidence from Russian Companies. Journal of General Management, 43, No. 2, pp. $51-62$. DOI: $10.1177 / 0306307017740182$.

LATUKHA, M. - VESELOVA, A. (2019): Talent Management, Absorptive Capacity, and Firm Performance: Does It Work in China and Russia? Human Resource Management, 58, No. 5, pp. 503 - 519. DOI: $10.1002 / \mathrm{hrm} .21930$.

LEBAS, M. - EUSKE, K. (2002): A Conceptual and Operational Delineation of Performance. Business Performance Measurement: Theory and Practice, pp. $65-79$. DOI: 10.1017/CBO9780511805097.008.

LEVENSON, A. (2012): Talent Management: Challenges of Building Cross-functional Capability in Highperformance Work Systems Environments. Asia Pacific Journal of Human Resources, 50, No. 2, pp. 187 - 204. DOI: 10.1111/j.1744-7941.2011.00022.x.

LENZ, M. V. - SCHMIDT, S. L. - SCHREYER, D. (2020): The Impact of Personality Traits on Talents' Performance throughout Development Phases: Empirical Evidence from Professional Football. Applied Economics, 52, No. 37, pp. 4073 - 4091. Available at: <https://doi.org/10.1080/00036846.2020.1730761>.

LOTFI, A. - HASANI, A. - ESFAHANI, S. A. (2020): Performance Assessment of Talent Management System via Using System Dynamic Approach and Scenario Planning. Case Study: Iran Falat-Qhare Oil Company. International Journal of Productivity and Quality Management, 29, No. 1, pp. $62-93$.

LYRIA, R. K. - NAMUSONGE, G. S. (2017): The Effect of Talent Retention on Organizational Performance of Firms Listed in the Nairobi Securities Exchange. Journal of Human Resource and Leadership, 1 , No. 3, pp. $18-30$. 
McDONNELl, A. - COLLINGS, D. G. - MELLAHI, K. - SCHULER, R. (2017): Talent Management: A Systematic Review and Future Prospects. European Journal of International Management, 11 , No. 1 , pp. $86-128$.

MEYERS, M. C. - van WOERKOM, M. - DRIES, N. (2013): Talent - Innate or Acquired? Theoretical Considerations and Their Implications for Talent Management. Human Resource Management Review, 23, No. 4, pp. 305 - 321. DOI: 10.1016/j.hrmr.2013.05.003.

MEY, M. R. - POISAT, P. - STINDT, C. (2021): The Influence of Leadership Behaviours on Talent Retention: An Empirical Study. SA Journal of Human Resource Management, 19, April, 9 p. Available at: <https://doi.org/10.4102/sajhrm.v19i0.1504〉.

MIHALCEA, A. (2017): Employer Branding and Talent Management in the Digital Age. Management Dynamics in the Knowledge Economy, 5, No. 2, pp. 289 - 306. DOI: 10.25019/MDKE/5.2.07.

MOHAMMED, A. (2016): The Impact of Talent Management on Employee Engagement, Retention and Value Addition in Achieving Organizational Performance. International Journal of Engineering and Management, 1, No. 12, pp. $142-152$.

NAMUSONGE, G. S. - KABARE, K. - KAGWIRIA, R. (2014): Effect of Talent Retention on Organisation Performance in Companies Listed in Nairobi Securities Exchange in Kenya. European Journal of Business and Social Sciences, 3, No. 1, pp. $47-58$. DOI: 10.6007/IJARBSS/v8-i5/4139.

NASIR, Y. S. - MOKTAR, S. - ARIFFIN, A. S. (2017): Effectiveness of Talent Management to Improving Organisational Performance in Government Owned Bank. Journal of Advanced Research in Business and Management Studies, 7, No. 1, pp. $32-38$.

N'CHO, J. (2017): Contribution of Talent Analytics in Change Management within Project Management Organizations the Case of the French Aerospace Sector. Procedia Computer Science, 121, pp. 625 - 629. Available at: <https://doi.org/10.1016/j.procs.2017.11.082〉.

OBLIOPAS, R. - AFABLE, F. - MADEJA, J. (2019): Talent Management: a Philippine State University Graduate School Experience. Indian Journal of Science and Technology, 12, No. 42, pp. 1 - 4. DOI: 10.17485/ijst/2019/v12i42/147908.

OLADAPO, V. (2014): The Impact of Talent Management on Retention. Journal of Business Studies Quarterly, 5, No. 3, pp. 19 - 36.

OLSEN, R. (2000): Harnessing the Internet with Human Capital Management. Workspan, 43, No. 11, pp. $24-27$.

O. NYUMBA, T. - WILSON, K. - DERRICK, C. J. - MUKHERJEE, N. (2018): The Use of Focus Group Discussion Methodology: Insights from Two Decades of Application in Conservation. Methods in Ecology and Evolution, 9, No. 1, pp. 20 - 32. Available at: <https://doi.org/10.1111/2041-210X.12860>.

OMOTUNDE, O. I. - ALEGBELEYE, G. O. (2021): Talent Management Practices and Job Performance of Librarians in University Libraries in Nigeria. The Journal of Academic Librarianship, 47, No. 2, pp. 102319. Available at: 〈https://doi.org/10.1016/j.acalib.2021.102319〉.

OREG, S. - BARTUNEK, J. M. - LEE, G. - DO, B. (2018): An Affect-based Model of Recipients' Responses to Organizational Change Events. Academy of Management Review, 43, No. 1, pp. 65 - 86. Available at: 〈https://doi.org/10.5465/amr.2014.0335〉.

OZEL, A. - KARACAY, G. (2019): Identifying Talent Attributes for Talent Management in Automotive Industry in Turkey. Industrial Engineering in the Big Data Era, pp. 287 - 295. DOI: 10.1007/978-3-030-03317-0_24.

PAULI, U. - POCZTOWSKI, A. (2019): Talent Management in SMEs: an Exploratory Study of Polish Companies. Entrepreneurial Business and Economics Review, 7, No. 4, pp. $199-218$. DOI: 10.15678/EBER.2019.070412.

PERRIN, T. (2005): Winning Strategies for a Global Workforce: Attracting, Retaining and Engaging Employees for Competitive Advantage. Executive Report, 28 p.

RABBI, F. - AHAD, N. - KOUSAR, T. - ALI, T. (2015): Talent Management as a Source of Competitive Advantage. Journal of Asian business strategy, 5, No. 9, pp. 208 - 214. 
RAHIMPOUR, K. - SHIROUYEHZAD, H. - ASADPOUR, M. - KARBASIAN, M. (2020): A PCA-DEA Method for Organizational Performance Evaluation Based on Intellectual Capital and Employee Loyalty. Journal of Modelling in Management, pp. 1479 - 1513.

DOI 10.1108/JM2-03-2019-0060.

RAMAN, R. - CHADEE, D. - ROXAS, B. - MICHAILOVA, S. (2013): Effects of Partnership Quality, Talent Management, and Global Mind-set on Performance of Offshore IT Service Providers in India. Journal of International Management, 19, No. 4, pp. 333 - 346. Available at: 〈https://doi.org/10.1016/j.intman.2013.03.010>.

RUDITO, P. (2015): Leveraging Global Talent: Strategic Leverage to Achieve Excellent Business Performance. Advanced Science Letters, 21, No. 4, pp. 1064 - 1069. Available at: <https://doi.org/10.1166/asl.2015.5986>.

SAAR, S. S. (2013): The Challenge of Developing and Retaining Talent. Supply Chain Management Review, 17, No. 2, pp. 8 - 9 .

SADELI, J. (2015): The Influence of Leadership, Talent Management, Organizational Culture and Organizational Support on Employee Engagement. International Research Journal of Business Studies, 5, No. 3, pp. $1-21$.

SIDANI, Y. - AL ARISS, A. (2014): Institutional and Corporate Drivers of Global Talent Management: Evidence from the Arab Gulf Region. Journal of World Business, 49, No. 2, pp. 215 - 224. Available at: 〈https://doi.org/10.1016/j.jwb.2013.11.005>.

SILZER, R. - DOWELL, B. E. (eds) (2009): Strategy-driven Talent Management: A Leadership Imperative. San Francisco: John Wiley and Sons, 928 p.

SINGH, A. - JONES, D. B. - HALL, N. (2012): Talent Management: A Research Based Case Study in the GCC Region. International Journal of Business and Management, 7, No. 24, pp. 94 - 107. DOI: 10.5539/ijbm.v7n24p94.

SIVATHANU, B. - PILLAI, R. (2019): Technology and Talent Analytics for Talent Management - A Game Changer for Organizational Performance. International Journal of Organizational Analysis, 28, No. 2, pp. 457 - 473. Available at: 〈https://doi.org/10.1108/IJOA-01-2019-1634>.

SUN, J. - SONG, S. - WIPAWAYANGKOOL, K. - OH, J. S. (2019): Roles of Dynamic Capabilities and Knowledge Management Strategies on Organizational Performance. Information Development. Available at: 〈https://doi.org/10.1177/0266666919894377>.

TAFTI, M. M. - MAHMOUDSALEHI, M. - AMIRI, M. (2017): Critical Success Factors, Challenges and Obstacles in Talent Management. Industrial and Commercial Training, 49, No. 1, pp. 15 - 21. Available at: 〈https://doi.org/10.1108/ICT-05-2016-0036〉.

TANSLEY, C. (2011): What Do We Mean by the Term "Talent" in Talent Management? Industrial and Commercial Training, 43, No. 5, pp. $266-274$. Available at: <https://doi.org/10.1108/00197851111145853>.

TANSLEY, C. - TIETZE, S. (2013): Rites of Passage through Talent Management Progression Stages: An Identity Work Perspective. The International Journal of Human Resource Management, 24, No. 9, pp. 1799 - 1815. Available at: <https://doi.org/10.1080/09585192.2013.777542>.

THUNNISSEN, M. - BOSELIE, P. - FRUYTIER, B. (2013): Talent Management and the Relevance of Context: Towards A Pluralistic Approach. Human Resource Management Review, 23, No. 4, pp. 326 - 336. Available at: <https://doi.org/10.1016/j.hrmr.2013.05.004>.

THUNNISSEN, M. - van ARENSBERGEN, P. (2015): A Multi-dimensional Approach to Talent. Personnel Review, 44, No. 2, pp. $182-199$. Available at: <https://doi.org/10.1108/PR-10-2013-0190>.

TLAISS, H. (2021): Exploring Talent Management in Practice: An Arab Country-specific Empirical Investigation. Employee Relations, 43, No. 1, pp. 63 - 81. Available at: <https://doi.org/10.1108/ER-10-2019-0411>.

TOMCIKOVA, L. - SVETOZAROVOVA, N. - COCULOVA, J. (2021): Challenges and Priorities in Talent Management during the Global Pandemic Caused by COVID-19. Marketing and Management of Innovations, No. 2, pp. 94 - 103. Available at:

<http://doi.org/10.21272/mmi.2021.2-08>. 
TRIVEDI, S. - PANDYA, K. (2019): A Study on Relationship between HR Practices, Employee Performance and Organizational Productivity: An Empirical View of ITITEs Industry. Global Journal of Research in Management, 9, No. 1, pp. 97 - 114.

UDDIN, R. - ARIF, A. A. (2016): Talent Management and Organizational Performance: An Empirical Study in Retail Sector in Sylhet City, Bangladesh. IOSR Journal of Business and Management, 18, No. 10, pp. 11 - 18. DOI: 10.9790/487X-1810041118.

ULRICH, D. - SMALLWOOD, N. (2012): What is Talent? Leader to Leader, 63, pp. 55 - 61. Available at: <https://doi.org/10.1002/lt1.20011>.

VECCHI, A. - DELLA PIANA, B. - FEOLA, R. - CRUDELE, C. (2021): Talent Management Processes and Outcomes in a Virtual Organization. Business Process Management Journal, 27, No. 7, pp. 1937 - 1965. Available at: 〈https://doi.org/10.1108/BPMJ-06-2019-0227>.

ZHANG, S. - BRIGHT, D. (2012): Talent Definition and Talent Management Recognition in Chinese Private-Owned Enterprises. Journal of Chinese Entrepreneurship, 4, No. 2, pp. 143 - 163. Available at: 〈https://doi.org/10.1108/17561391211242753〉.

WEE, E. X. - TAYLOR, M. S. (2018): Attention to Change: A Multilevel Theory on the Process of Emergent Continuous Organizational Change. Journal of Applied Psychology, 103, No. 1, pp. 1 - 13. Available at: 〈https://doi.org/10.1037/ap10000261>.

WIBLEN, S. (2016): Framing the Usefulness of eHRM in Talent Management: A Case Study of Talent Identification in a Professional Services Firm. Canadian Journal of Administrative Sciences/Revue Canadienne des Sciences de l'Administration, 33, No. 2, pp. 95 - 107. Available at: 〈https://doi.org/10.1002/cjas.1378>.

ZHELTOUKHOVA, K. (2014): HR: Getting Smart about Agile Working. [CIPD Research Report.] London: CIPD, $38 \mathrm{p}$.

ZIRAR, A. - TRUSSON, C. - CHOUDHARY, A. (2020): Towards a High-performance HR Bundle Process for Lean Service Operations. International Journal of Quality and Reliability Management, 38, No. 1, pp. 25 - 45. Available at: <https://doi.org/10.1108/IJQRM-10-2019-0330>. 